\title{
Slope Stability in a Mining Environment M'haoudatt-Zouerate Site, Mauritania
}

\author{
Ahmed Hemed, Latifa Ouadif \\ 3GIE Laboratory, Mohammedia School of Engineering, Med V University of Rabat, Rabat, Morocco \\ Email address: \\ ouldhemed@gmail.com (A. Hemed) \\ To cite this article: \\ Ahmed Hemed, Latifa Ouadif. Slope Stability in a Mining Environment M'haoudatt-Zouerate Site, Mauritania. American Journal of Energy \\ Engineering. Vol. 9, No. 3, 2021, pp. 85-90. doi: 10.11648/j.ajee.20210903.13
}

Received: August 12, 2021; Accepted: August 25, 2021; Published: September 6, 2021

\begin{abstract}
The instability of the M'HAOUDATT pit is a major problem often encountered on the wall composed of a network of fractures located in unfavorable conditions for a very soft geological formation. Therefore, the trend in large openpit mines is to use high-energy blasting to increase conveying performance and crusher throughput. The increase in blasting energy concentration can threaten the integrity of the pit wall. In this paper, we aim to find a suitable plan to stabilize the pit deposit, through analyses of structural and lithological data on the pit walls, with an interpretation of the lateral and depth extensions according to the geological complexity of the deposit. Followed by an analytical treatment of the current pit parameters. Data processing included core classification, kinematic assessment of failure mechanisms based on visual observations on the exposed faces of the expected pit. The results of the laboratory tests were also used to define the rock mass parameters used to establish a stable slope design. The analyses showed the need for an effective strategy to ensure that the slopes won't be damaged by blasting. This wall control strategy aims to produce a fragmented bulk ore pile and a slope as designed and in good condition. A good understanding of the failure mechanisms is necessary to ensure better monitoring of the rock slopes of the M'HAOUDATT pit.
\end{abstract}

Keywords: M'haoudatt, Tiris Zemmour, Pit Slope, Hematite

\section{Introduction}

The M'HAOUDATT mine is composed of several weak zones, generating instability all along the pit wall plus the roof and pit closures.

The MHDT deposit is a naturally rich iron ore deposit (hematite), located $55 \mathrm{~km}$ north-east of Zouerate-Mauritania.

To get this work off to a good start, we begin to define the fracturing of the terrain to assess the influence of the discontinuities affecting the rock mass.

Fracture survey processing shows a series of fractures of several families, which have the same geometric characteristics both at surface and at depth;

The preponderance between all the families of discontinuities and the geological contact zones always generates the first phenomenon of instability in the M'HAOUDATT pit.

A combination of empirical and analytical calculations was carried out in order to dimension the step angle, the interramp and the integrating slope of each pit face [5].
The MHDT pit slopes have a specific design based on the nature of the terrain, the geomechanical parameters and the characteristics of the rock that constitutes it.

These parameters are used in empirical classification (RQD, Barton Q, Bieniawski RMR, GSI) to assess the quality of the terrain, and to take advantage of the correlation rules between the different methods to deduce the other parameters $[7,10]$.

These data allowed the analysis of the failure mechanisms that can realistically affect the slopes.

The interpretation of the majority of the analyses can guide us to propose slope angles according to their safety orientations.

A set of analyses are called for to identify the families causing these different failure modes in each sector of the pit.

And subsequently, the overall stability of the dimensioned pit was exposed by appropriate software based on analytical and numerical methods (the finite element method) plus the design of these parameters through the recommended pit lining.

Finally, a blast effect analysis was carried out to determine the response of the rock mass to the type of explosive used. 


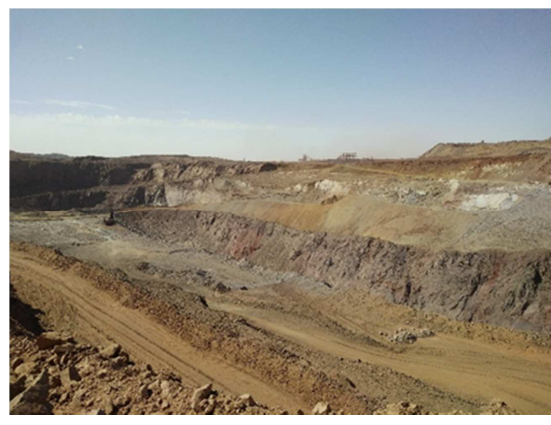

Figure 1. M'HAOUDATT pit.

\section{Geology of the Site}

The M'HAOUDATT unit is made up of three main groups of facies: common iron facies, special iron facies, the most important of which is the jasper facies, and non-iron facies.

The range is formed almost entirely of BIF (containing iron mineralisation consisting of hematite and other iron oxides), with some quartzite units and shales.

\section{Identification of the Problem}

\subsection{Processing of Cell Surveys}

The pit facings consist of roof, wall and closure, the walls are structurally controlled by the bedding orientations and schistosities. The roofs and closures are controlled mainly by the different families of diaclases in relation to the front and the orientations of the bedding.

With the naked eye we can see a break on planar surfaces concerning a part of the wall which is released on a single plane of discontinuity (Figure 2), this is due to the fact that the measured contact joints present a lower dip of the interramp which makes this kind of break very unlikely.

The planar break created by the families sub-parallel to the wall of pit M'HAOUDATT, presents problems for the stability of the slopes, due to its alteration and the dip towards the pit.

The wedge fracture reported in the roof zone of the pit is observed in terms of the intersection between two families of joints, a folding phase (Figure 3 ) and the presence of vertical seams that shear the rock mass (Figure 4).

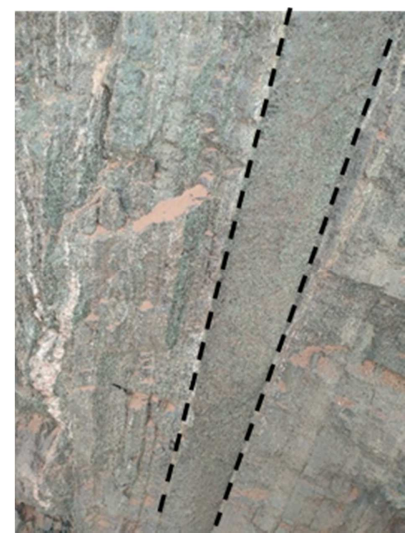

Figure 2. Discontinuity plane in the wall.

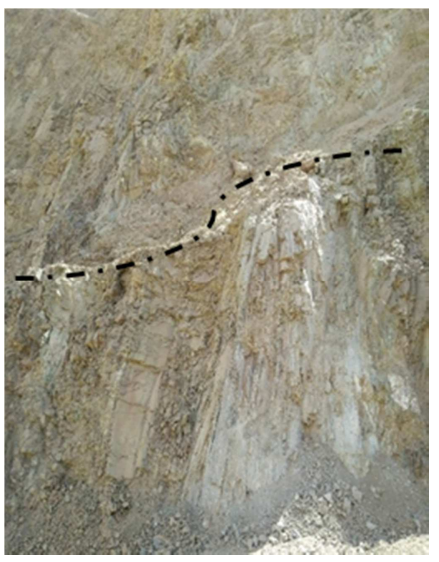

Figure 3. Fracture due to a fault in the roof.

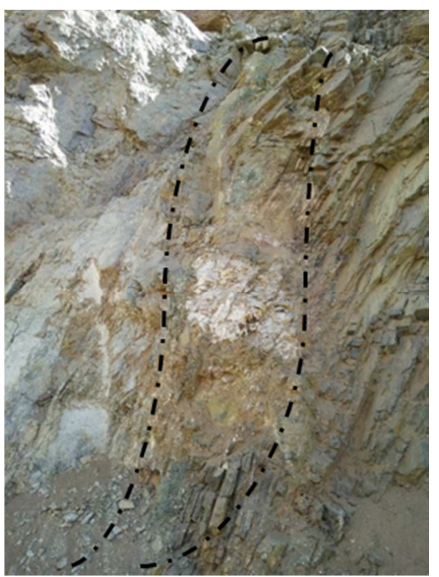

Figure 4. Quartzite shear vein in the roof.

\subsection{Realization of the Fronts}

Integrative slopes and frontage slopes achieved are different from those planned.

The slopes of the discontinuities are lower than those of the fronts.

The absence of safety benches at the planned levels.

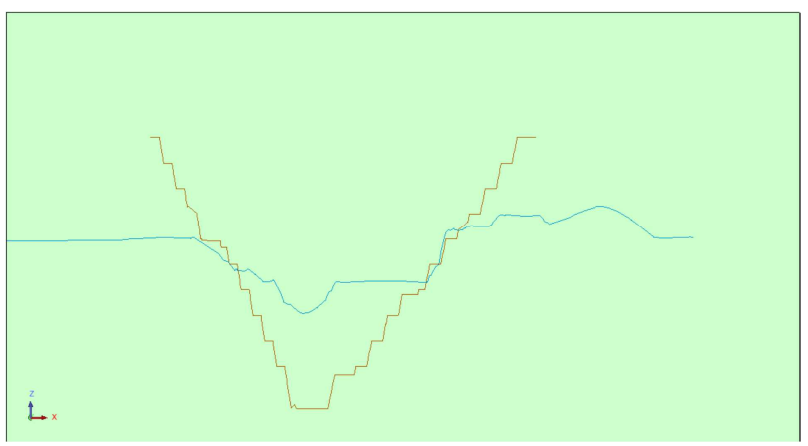

Figure 5. Cross-section of the pit as compared to the recommended pit.

\subsection{The high Impact Energy on Fractured Rocks}

This difference in measurement generates large-scale instabilities by plane rupture, on the pit wall, with detachment of the blocks between the upper levels.

This difference in realisation leads to higher than expected overdraft rates. 


\section{Resizing of the M'HAOUDATT Pit}

A resizing of the pit is proposed as a corrective measure to ensure safe and profitable operation [2].

The input data for this section is summarised in the following table:

Table 1. Pit parameters tested.

\begin{tabular}{lll}
\hline \multirow{2}{*}{ Parameters } & Tested values & Roof \\
\cline { 2 - 3 } & Wall & $65^{\circ}-70^{\circ}-75^{\circ}-80^{\circ}$ \\
\hline angle $\left(^{\circ}\right)$ & $60^{\circ}-65^{\circ}-70^{\circ}-75^{\circ}$ & $10 \mathrm{~m}-12 \mathrm{~m}-15 \mathrm{~m}$ \\
height $(\mathrm{m})$ & $10 \mathrm{~m}-12 \mathrm{~m}-15 \mathrm{~m}$ & 40 à $60^{\circ}$ \\
Integrative slope of the pit $\left(^{\circ}\right)$ & 40 à $60^{\circ}$ & \\
\hline
\end{tabular}

A kinematic analysis aims to identify the families causing these different failure modes in each front of the pit. Another deterministic analysis aims to assess the different behaviours by calculating the safety factor each time there is a potential for sliding along one or two planes [1].
An empirical approach is used together with analytical methods to dimension the integrating slopes [4].

In this analysis we adopt a minimum security value of 1.3 which gave us the results after all calculations were done:

Table 2. Summary of results.

\begin{tabular}{|c|c|c|c|c|c|c|c|c|c|}
\hline \multirow{2}{*}{ Pit } & \multirow{2}{*}{ Sector } & \multicolumn{2}{|l|}{ Stands } & \multirow{2}{*}{$\begin{array}{l}\text { Integrating slope } \\
\text { Angle }\left(^{\circ}\right)\end{array}$} & \multicolumn{2}{|c|}{ Inter-ramp } & \multirow{2}{*}{$\begin{array}{l}\text { Safety seat } \\
\text { (m) }\end{array}$} & \multirow{2}{*}{\begin{tabular}{|l|} 
Ramp \\
Width (m) \\
\end{tabular}} & \multirow{2}{*}{\begin{tabular}{|l|} 
Berme \\
Width (m) \\
\end{tabular}} \\
\hline & & H (m) & Angle $\left({ }^{\circ}\right)$ & & H (m) & Angle ( $\left.{ }^{\circ}\right)$ & & & \\
\hline \multirow{2}{*}{ M'HAOUDATT } & Roof & \multirow{2}{*}{12} & 73 & 55 & \multirow{2}{*}{3} & 62 & 12 & $24-30$ & 4 \\
\hline & Wall & & 63 & 48 & & 54 & 13 & $24-30$ & 4 \\
\hline
\end{tabular}

The results obtained from all the analyses are verified by numerical and analytical methods using appropriate software [3], and this confirms the stability of the recommended geotechnical parameters, as the tools used (software for the evaluation of planar sliding and dihedral failure) take into consideration quantitative parameters, in particular the geomechanical and geotechnical parameters for the design of stable pits [9].

\section{Impact of Recommended Parameters}

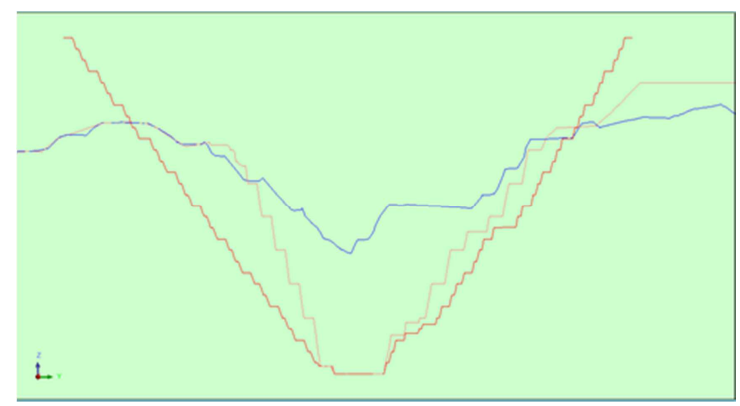

Figure 6. Cross section between the 3 pits.

The lining of the pit with the determined geotechnical parameters generates changes in the shape and quantity removed from the deposit, this change is explained by the following graph:

The new design increases the overdraft rate through the effect of:

The steep wall slope of the ultimate pit.

The absence of safety benches in the lower levels of the final pit.

The distance of the catchment berms from the recommended pit.

\section{Analysis of the Effect of the Production Shots}

During a visit to the M'HAOUDATT pit construction site, we found that the positioning of the blasting holes, their loading with explosives, and the undercutting of the loading shovels play a major role in the instability of the pit. Therefore, we will start this analysis of the effect of blasting on the pit walls of the M'HAOUDATT pit [12].

Abbreviation used:

BHQ: Quartzite Hematite Bands

H: Hematite

Sch: Shale

Table 3. Mechanical parameters of MHDTT rock.

\begin{tabular}{lllllll}
\hline & $\begin{array}{l}\text { Speed of } \\
\text { sound }(\mathbf{m} / \mathbf{s})\end{array}$ & Density $\left(\mathbf{g} / \mathbf{c m}^{\mathbf{3}}\right)$ & $\begin{array}{l}\text { Compressive } \\
\text { strengthsingle (MPa) }\end{array}$ & $\begin{array}{l}\text { Indirect tensile strength } \\
\text { (MPa) BRAIZILIAN Trial }\end{array}$ & $\begin{array}{l}\text { Young's modulus } \\
(\mathbf{M P a})\end{array}$ & $\begin{array}{l}\text { Poisson's } \\
\text { ratio }\end{array}$ \\
\hline BHQ & 3933 & 3.08 & 148.6 & 19.5 & 47642,77 & 0.308 \\
H & 5231 & 4.56 & 222.7 & 10.4 & 124795,11 \\
Sch & 3045 & 2.47 & 30.38 & 3.6 & 9.19 & 22900 \\
\hline
\end{tabular}

Laboratory testing of fractures and inctact rock were prformed in 2005. Laboratory test results, along with RQD data from core drilling, were used to estimate rock mass strengths for the overall slope analyses [11, 3]. 
Table 4. Characteristics of the explosive.

\begin{tabular}{llllll}
\hline Designations & Density $\left(\mathbf{g} / \mathbf{c m}^{\mathbf{3}}\right)$ & Detonation velocity $\mathbf{~} / \mathbf{s}$ & $\begin{array}{l}\text { Critical detonation } \\
\text { diameter }(\mathbf{m m})\end{array}$ & Water resistance & Area of use \\
\hline ANFO & 0.8 & 3200 & $50-55$ & Low & Medium and soft rocks \\
Emulsions & 1.3 & 5000 & $20-40$ & Excellent & Hard and wet rocks \\
\hline
\end{tabular}

Transfer of detonation energy:

The work of the detonation pressure wave which is responsible for the fragmentation of the rock [13].

This pressure wave is calculated to evaluate their transfer by a CPF factor must be between $[0.7 ; 1]$,

The pressure of the shock wave generated by the explosive is approximated by (CHAPMANN-JOUGUET):

$$
P=2.5 \rho D^{2} 10^{-6}
$$

P: Detonation pressure in kbar

$\rho$ : Specific gravity of the explosive

$\mathrm{C}$ : Detonation velocity in $\mathrm{m} / \mathrm{second}$

The detonation pressure can be expressed as a function of the detonation velocity according to some authors:

$$
\mathrm{p}=\frac{4.18 \times 10^{-7} D C^{2}}{1+0.8 D}
$$

P: Detonation pressure in kbar (1 kbar $=14,504 \mathrm{psi})$

D: Specific gravity of the explosive

C: Detonation velocity in feet/second $(1 \mathrm{~m}=3.2808$ feet $)$

According to the approach of Teller (1985): He defines the acoustic impedance $\mathrm{Z}$ of the rock:

$$
Z=1.31 \rho \frac{V_{S}}{1000}
$$

$\rho:$ is the density of the rock

Vs: is the ultrasonic velocity in the rock in $\mathrm{ft} / \mathrm{s}$

It defines the characteristic factor CPF of the explosive:

$$
C P F=\frac{Z}{P}
$$

Where $\mathrm{P}$ is the detonation pressure in kbar.

\begin{tabular}{|c|c|c|c|c|c|c|c|c|c|c|}
\hline \multirow{5}{*}{ Designations } & \multirow{5}{*}{$\begin{array}{l}\text { Density } \\
\mathrm{g} / \mathrm{cm}^{3}\end{array}$} & \multirow{5}{*}{$\begin{array}{l}\text { Detonation } \\
\text { speed } \mathrm{ft} / \mathrm{s}\end{array}$} & \multirow{5}{*}{$\begin{array}{l}\text { Detonation } \\
\text { pressure (other } \\
\text { authors) }\end{array}$} & \multirow{5}{*}{$\begin{array}{l}\text { Detonation pressure } \\
\text { (CHAPMANN- } \\
\text { JOUGUET) }\end{array}$} & \multicolumn{3}{|c|}{ transfer of detonation energy } & \multicolumn{3}{|c|}{ transfer of detonation energy } \\
\hline & & & & & \multicolumn{3}{|c|}{$Z$ de la roche TELLER } & \multicolumn{3}{|c|}{$\mathrm{Z}$ de la roche TELLER } \\
\hline & & & & & BHQ & $\mathbf{H}$ & Sch & BHQ & $\mathbf{H}$ & Sch \\
\hline & & & & & 15,87 & 31,25 & 9,85 & 15,87 & 31,25 & 9,85 \\
\hline & & & & & CPF & & & CPF & & \\
\hline ANFO & 0,8 & 10498,56 & 22,47 & 20,48 & 0,71 & 1,39 & 0,44 & 0,77 & 1,53 & 0,48 \\
\hline Emulsions & 1,3 & 16404 & 71,68 & 81,25 & 0,22 & 0,44 & 0,14 & 0,20 & 0,38 & 0,12 \\
\hline
\end{tabular}

This factor must be between:

$0.7<\mathrm{CPF}<1$.

Table 5. Detonation energy transfer.

The pressure increases as the velocity of detonation increases i.e. with increasing the diameter of the felling holes [8].

We find that the Emulsion and ANFO explosives have a higher detonation velocity or density than is required to fragment the M'HAOUDATT pit rocks, and the ANFO explosive has a lower detonation velocity or density than is required to fragment the hematite ore [14].

\subsection{Energy Transfer in the Massif}

This transfer is evaluated by an impedance ratio between the explosive and the fragmented rock:

$$
\frac{E_{t r}}{E_{i}}=\frac{4 Z}{(1+Z)^{2}}
$$

With: Impedance $Z=\frac{\rho_{\mathrm{e}} \mathrm{D}}{\rho_{\mathrm{r}} \mathrm{V}_{\mathrm{r}}}$ ratio (established by analogy).

$\rho_{e}$ et $D$ Density and detonation velocity of the explosive.

$\rho_{r}$ et $V_{r}$ Density and speed of wave propagation in rock.

This theory is thus based on a series of experimental measurements giving a range of interesting values for the impedance ratio $Z$. This $Z$ value should be between 0.4

\begin{tabular}{|c|c|c|c|c|c|c|}
\hline \multirow{2}{*}{ Designations } & \multicolumn{2}{|c|}{ BHQ } & \multicolumn{2}{|l|}{$\mathrm{H}$} & \multicolumn{2}{|l|}{ Sch } \\
\hline & $\mathbf{Z}$ & Transmitted energy & $\mathbf{Z}$ & Transmitted energy & $\mathbf{Z}$ & Transmitted energy \\
\hline ANFO & 0,21 & 0,58 & 0,11 & 0,35 & 0,34 & 0,76 \\
\hline Emulsions & 0,54 & 0,91 & 0,27 & 0,67 & 0,86 & 0,99 \\
\hline
\end{tabular}
and 0.7 (experimentally established corrective coefficients).

$$
0.4<\frac{I_{e}}{I_{r}}<0.7
$$

Table 6. Energy transfer in the massif.

Based on a simulation on the I-BLAST software [6], for fragmentation by both types of explosives and the impedance ratio approach, we can therefore determine the types of explosives that can be used for foot shear at M'HAOUDATT pit. Considering these aspects, the only explosive that is a priori powerful enough is Emulsion. 
However, the low $\mathrm{Z}$ value for the nitrate-oil raises the question of whether this explosive is really suitable for the type of rock mined in M'HAOUDATT. According to this approach, the energy developed by the ANFO explosive would be rather poorly transmitted to the rock mass. However, this study does not fully take into account the energy losses in the annular space for encartouchés; nitrateoil, which is in bulk form, fills the hole completely, which could explain its good efficiency compared to other encartouché emulsions.

This study proposes a design for an adaptable firing plan for the M'HAOUDATT pit. This design is found in detail in the body of the study.

\subsection{Pre-cutting}

Pre-cutting with explosives is the first time the charges are fired to create a crack that will stop the propagation of vibrations to the mass [15].

The creation of such a row helps to protect the catchment benches on the desired levels, to keep the frontage intact in place.

This line eliminates micro-fracturing which can develop over time into a family of ruptures responsible for block collapse.

The layout of the holes and the geometry of a flight at the final face should be done with the tightening of the hole mesh of the rows closer to the final pit face to spare the casing area as much as possible.

This layout must be carried out according to the different lithological facies existing in the pit.

The diameter of the holes in this line is estimated by $\Phi p=$ 4.5 inches in the pit roof and by $\Phi p=4$ inches in the wall.

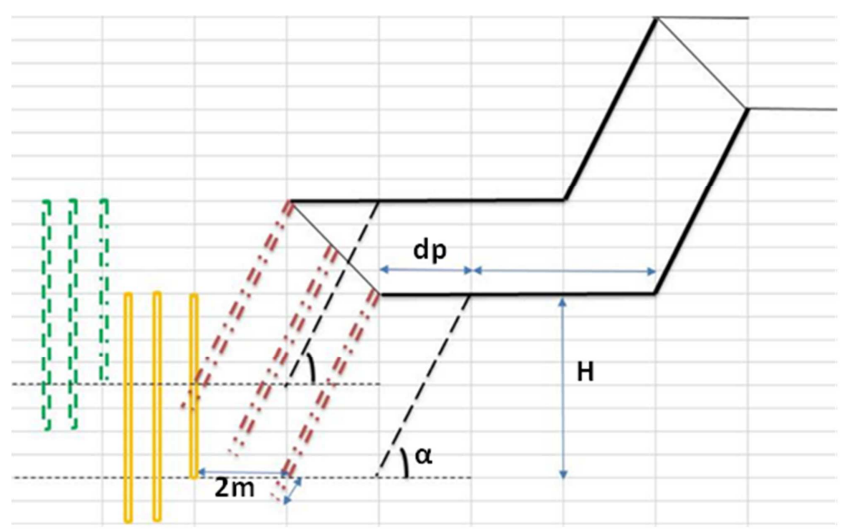

Figure 7. Hole layout of a complete flight.

Elements of calculation:

Table 7. Calculation of the parameters of a pre-cutting line.

\begin{tabular}{|c|c|c|c|c|}
\hline & \multicolumn{2}{|c|}{ height $H(m)$} & \multicolumn{2}{|l|}{12} \\
\hline & \multicolumn{2}{|l|}{ Wall } & \multicolumn{2}{|l|}{ Roof } \\
\hline & $\alpha\left({ }^{\circ}\right)$ & 63 & $\alpha\left({ }^{\circ}\right)$ & 73 \\
\hline Diameter (m) & 0,1016 & & 0,1143 & \\
\hline Load height (m) & 8,98 & & 8,37 & \\
\hline Volume of explosives/hole $\left(\mathrm{m}^{3}\right)$ & 0,07 & & 0,09 & \\
\hline Distance dp (m) & 3,06 & & 1,83 & \\
\hline Hole depth (m) & 13,47 & & 12,55 & \\
\hline Over depth (m) & ANFO & EMULSION & ANFO & EMULSION \\
\hline Tonnage of explosives required $(\mathrm{T})$ & 0,058 & 0,095 & 0,069 & 0,112 \\
\hline Tonnage of explosives required $(\mathrm{kg})$ & 58,23 & 94,63 & 68,67 & 111,59 \\
\hline Specific consumption $(\mathrm{t} / \mathrm{m})$ & 0,006 & 0,011 & 0,008 & 0,013 \\
\hline Specific consumption $(\mathrm{kg} / \mathrm{m})$ & 6 & 11 & 8 & 13 \\
\hline
\end{tabular}

There is a delay of $160 \mathrm{~ms}$ between the jumping of the precutting row and the main firing. Once this row is completed and the blast is effective, a new free surface will be created for the next row, and so on until the last row is fired.

Pre-cutting is highly recommended in the wall of pit M'HAOUDATT, containing highly stained talcs.

The respect of the mesh between the holes and the back effect.

Always make sure that the holes in the last row are correctly located, holes that do not conform must be redrilled.

A depth control, and load and ensure that they are uniform for all holes.

\subsection{Recommendations}

Ensures that the recommended geotechnical parameters are applied.
Minimising central fire on M'HAOUDATT site.

Use previously shot volleys as a clearing surface.

The reduction of the detonation energy sent to the rock mass by respecting the recommended diameters of the drill holes.

Pre-cutting is very essential in shale areas.

Cleaning of the fronts after loading the felled material, the excavators must clear the fronts to remove the blocks that remain suspended and to prevent these blocks from falling.

All safety benches must be cleaned after blasting. This is to prevent the filling of these benches and consequently the falling of blocks onto the mining areas.

Special monitoring for the final pit faces through equipment installed on the benches of the kind: prisms!

Field monitoring with the help of a support system.

\section{Conclusion}

The M'HAOUDATT pit is unstable due to the operating 
conditions, therefore compliance with geotechnical parameters is required from the operators.

The last row should be drilled without overdrilling, separated by a distance of $2 \mathrm{~m}$ from the pre-cut line loaded with $80 \%$ of the normal load.

We can always think of setting up a slope monitoring method (by radar, crack extensometers, drilling inclinometers, prisms, etc.) to reduce the risk associated with the identification of slope instabilities.

\section{References}

[1] Bieniawski, Z. T. 1976. Rock mass classifications in rock engineering; In Exploration of Rock Engineering, Z. T. Bieniawski (ed.) A. A. Balkema, Cape Town.

[2] Bishop A. W., The use of the slip circle in the stability analysis of slopes. Geotechnics, V5.

[3] Roc science Inc. (1989-2002), Dips, Plotting, Analysis and Presentation of Structural Data.

[4] AFILAKA J. O., 1988, Analyse de la stabilité des talus en mines à ciel ouvert, approche probabiliste, application à la mine de Carmaux. Thèse Ecole Nationale Supérieure des Mines de Paris.

[5] ROMANA M., SERON J. B. and MONTALAR E. (2003), SMR Geomechanics classification: Application, experience and validation, Polytechnic University of Valencia, Spain.

[6] GENEVIEVE A. (2000), Étude et programmation de l'algorithme du flot maximum appliqué aux problèmes de contours ultimes dans une mine à ciel ouvert, Mémoire
Maitrise es Sciences appliqués, École Polytechnique de Montréal, CANADA.

[7] BONNART J. M., FEUGA B. et ROCHE J., 1981 Carmaux Stabilité des talus réalisés dans les formations tertiaires, BRGM, 81 SGN 355 MPY, Mars 1981.

[8] Atchison, T. C. and Puglies, J. M, Comparative studies of explosives in granite. II series of tesis, U.S. bureau of mines, R. I. 6434, 1964.

[9] CROQUET P., WOJTKOWIAK F., 1990 Boulonnage par câbles d'ancrage des excavations minières en massif rocheux fracturé. Ind. Minérale - Mines et Carrières.

[10] Hino K, Fragmentation of Rock Through Blasting. J. Ind. Exp. Soc, (1956), Japan.

[11] HADADOU R., 1988 Etude de la stabilité de la découverte des Fouthiaux- Houillères de Blanzy. Application du programme SARMA. Mémoire de DEA. Laboratoire de Mécanique des Terrains. Ecole des Mines de Nancy, 1988.

[12] Philipponat G. (1979). Fondations et ouvrages en terre. Ed. Eyrolles. Paris. 402 p.

[13] Campy M., Macaire J. J., (2003). Géologie de la surface. Erosion, transfert et stockage dans les environnements continentaux. Dunod. Paris. 488 p.

[14] Simakine V. (1986). Projet d'exploitation du gisement calcaire Medjounès pour une période de cinq années de 1985 à 1990 . Notice explicative. Rapport inédit. U.R.E.G. 35 P.

[15] Dawson, E. M., Roth, W. H., and Drescher, A. 1999. Slope Stability Analysis by Strength Reduction, Geotechnique, vol. 49 , no. 6 , pp. $835-840$. 